\title{
Neoliberalism in Britain: From Thatcherism to Cameronism
}

\section{Christian Fuchs}

\author{
University of Westminster: Communication and Media Research Institute (CAMRI), West- \\ minster Institute for Advanced Studies (WIAS). London, UK, christian.fuchs@uti.at, \\ http://fuchs.uti.at
}

\begin{abstract}
The Conservative Party has in the 2015 British general elections won an absolute majority under David Cameron's leadership. Cameron's rule signifies a contested phase in British politics in the 21st century. This paper asks the question: What is Cameronism? Cameron argues that Margaret Thatcher "was a big influence" for him. It is therefore appropriate to study the relationship between Thatcherism and Cameronism. The article revisits theories of Thatcherism and analyses how it is related to Cameronism. Thatcherism and Cameronism are understood as being unities of ideology and policies that want to implement a particular model of society and for doing so, are organised along three dimensions: the economy, politics, and culture. An ideology critique of key speeches, interviews and documents analyses these three dimensions of Cameronism.
\end{abstract}

Keywords: Cameronism, David Cameron, political discourse, ideology, Margaret Thatcher, Thatcherism

\section{Introduction}

The 2015 British general elections resulted in the Conservative Party's absolute majority. This outcome was unexpected because all opinion polls had predicted a head-to-head race between the Labour Party and the Conservatives as well as a hung Parliament. Whereas the Tories governed in a coalition together with the Liberal Democrats from 2010-2015, the political period from 2015-2020 in Britain means a one party government with David Cameron as Prime Minster. It is a time of potential conjunctures, such as the EU Referendum and the tension between social democracy in Scotland under the Scottish National Party (SNP) and neoliberalism in England under Cameron.

Cameron's rule will probably overall last 10 years and be a significant period in British political history just like the Thatcher period from 1979 until 1990. This paper therefore asks: What is Cameronism? For doing so, it also poses the question: What was and is Thatcherism?

In the 2015 UK general elections, the Tories reached the relative majority of voters in the following groups ${ }^{1}$ : age group $35+$, social classes $A B$ (upper middle class and middle class) $(45 \%)$ and $C_{1}$ (lower middle class = professionals) $(41 \%)$, house owners $(46 \%)$, and mortgage holders (39\%). Members of social group DE (semi-skilled and unskilled working class, casual workers, pensioners, unemployed) voted predominantly for Labour (42\%). The social group C2 of skilled manual workers voted to the same extent (32\%) for Labour and Tories. $19 \%$ belonging to this social group voted for the UK Independence Party (UKIP) so that it is also UKIP's largest social group of voters (AB: $8 \%, C 1: 11 \%, C 2: 19 \%$, DE: $17 \%$ ). $51 \%$ of skilled manual workers (C2) and $44 \%$ of the DE group voted for the Tories or UKIP. This means that the traditional working class to a larger extent voted for right-wing parties than for Labour. The general turnout was $66 \%$. In the DE group it was only $57 \%$, in the age group 18 24 only $43 \%$, and among private renters only $51 \%$. A significant share of the young and the lower class did not feel represented by any political party, which shows that Labour's loss partly has to do with the lack of its appeal to such groups. Furthermore, the fact that a signifi-

\footnotetext{
1 IPSOS-MORI: How Britain voted in 2015, https://www.ipsos-mori.com/researchpublications/researcharchive/3575/How-Britain-voted-in2015.aspx?view=wide
} 
cant share of the C2 and DE voters cast their ballot for the Tories or UKIP shows a profound ideological phenomenon, in which parties that do not represent working class interests mobilise this class's voters by popular ideologies. Ideology is not the only, but an important aspect of Cameronism that needs to be studied in detail.

Section 2 revisits theorising Thatcherism and identifies specific elements. Section 3 presents an ideology critique of key speeches, documents and interviews in order to analyse elements of Cameronism. Section 4 compares Cameronism and Thatcherism. Section 5 draws political conclusions.

\section{Thatcherism Revisited}

The study of Thatcherism has developed as a special topic in critical theory, covering a broad range of literature. This paper cannot provide an in-depth discussion of such definitions and approaches, but has to restrict itself to providing examples.

\section{Thatcherism as Political Phenomenon}

Eric J. Evans (2013) characterises Thatcherism as a fusion of neoliberal economic policy making and authoritarian state politics in matters of the nation, the military, law and order, crime and the police. "She believed in: individual rights, particularly in economic matters; private enterprise within a free market; firm, sometimes authoritarian, leadership; low levels of personal taxation; union and vested-interest bashing; simple, unqualified, patriotism" (Evans 2013, 3).

Hay and Farrall (2014) understand Thatcherism as a combination of neo-liberalism and neo-conservatism characterised by "distrust of 'big' government; support for 'traditional values' (however defined); a focus on the 'freeing' of the economy from the control of the state; a reliance on the market as the most efficient mechanism for resource distribution and an associated normative commitment to the sanctity of the individual and individual choice" (Hay and Farrall 2014, 9).

Hay and Farrall argue that a key question for theorising Thatcherism is a) if it is the political period 1979-1990 in Britain or a general political model; and b) if it is understood as an ideology, as for example Stuart Hall and Peter Hall suggest in their analyses (Hall P. 1986, Hall S. 1988a, 1988b, Hall and Jacques 1983, 1989), or a set of concretely implemented policies, as David Marsh and Rod Rhodes (1992) argue. Hay and Farrall take an evolutionary perspective that combines the ideology and policy dimensions and traces for different dimensions of society the degree of Thatcherism's policy radicalism.

\section{Stuart Hall: Thatcherism as Authoritarian Populism}

Stuart Hall argues that economic crises, such as the one in the mid-1970s, do not determine political and ideological developments, but often initiate phases of profound ideological struggle. Thatcherism would have been a successful ideological response of right wing forces to the crisis that was successful based on the weakness of the political Left (such as the Labour Party) that could not sufficiently reach the popular sentiments of the working class. Thatcherism is for Hall the ideology of authoritarian populism that with its political imagery reaches out to big and small businesses, the middle class, and parts of the working class (especially in the South of England): It combines an intensification of coercive state power with ideological scapegoating. The first includes for example

"the extension, over the period, of police power and surveillance of political groups and individuals; the use of police and legal apparatuses in a wide area of social conflicts; the role of the judicial forces in containing the economic and industrial class struggle; the employment of new judicial instruments-the Industrial Relations Act, legal constraints on picketing and strikes; the extension of the conspiracy charge and political 
trials; the abuse of habeas corpus under a loose definition of 'emergency"' (Hall 1988a, 136).

Thatcherism "meant reversing the trend to state-subsidized welfare, breaking the curve of public spending and the public sector, restoring private enterprise and the imperatives of the free market and of free-market forces, rolling back the tide of state intervention, underpinning profitability, keeping wages in check, and breaking the power the working class had come to exercise in society, via the trade unions, in economic and political life" (Hall 1988b, 39).

Thatcherism combines law and order politics that use the "legal apparatuses" for "containing social and industrial conflict" (Hall 1988a, 136) with populist right-wing ideologies that in moral panics scapegoat specific groups, such as radical trade unionists ${ }^{2}$, left-wing intellectuals ${ }^{3}$, the bureaucratic welfare state that is said to limit the freedom and choice of hard working

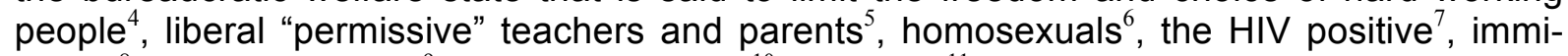
grants $^{8}$, the unemployed ${ }^{9}$, welfare recipients ${ }^{10}$, criminals $^{11}$, etc. Thatcherism contains a "new

${ }^{2}$ Thatcher: "Third, by heaping privilege without responsibility on the trade unions, Labour have given a minority of extremists the power to abuse individual liberties and to thwart Britain's chances of success. [...] Too often trade unions are dominated by a handful of extremists who do not reflect the common-sense views of most union members"

(Conservative General Election Manifesto 1979, http://www.margaretthatcher.org/document/110858)

3 Thatcher: "The old virtues of patriotism and national pride have been denigrated in the name of internationalism, love of all our fellow-men. But no one can love mankind if he does not love his own countrymen. It was the radical Socialist writer and patriot, the late George Orwell, who described the left-wing intellectuals as men motivated primarily by hatred of their own country. Socialists who spoke most about brotherhood of man [sic] could not bear their fellow-Englishmen, he complained"

(October 19, 1974, http://www.margaretthatcher.org/document/101830).

4 Thatcher: "The Welfare State has not abolished poverty despite a massive bureaucracy, unnecessarily high taxation, the invasion of personal choice and family life, and a grotesque inflation of government. Despite these high costs it has not brought the equality for which it was designed; and it has been kept going by intellectual conservatism, by bureaucratic inertia and by continuous repetition of claims it has not so far established and shows no prospect of ever establishing. [...] the paternalism of the Welfare State in which the consumer, especially in the working classes, is given what officials or social workers think is good for him, should be replaced by participation in which consumers of welfare are consulted and involved; and "consumerism" through representatives should increasingly be replaced by direct methods in which every man and woman has a personal say; [...] a new social policy should be built to combine humanity with dignity. It would liberate people to spend more on welfare than they will pay in taxation that is divorced from the service they receive. It would command the support of the many, not least the mass of wage earners, a large part of whose incomes is taken from them and spent by officials, mostly in ways that give them little say"

(September 19, 1979, http://www.margaretthatcher.org/document/110860).

${ }^{5}$ Thatcher: "But it's the plight of individual boys and girls which worries me most. Too often, our children don't get the education they need-the education they deserve. And in the inner cities-where youngsters must have a decent education if they are to have a better future-that opportunity is all too often snatched from them by hard left education authorities and extremist teachers. And children who need to be able to count and multiply are learning anti-racist mathematics-whatever that may be. Children who need to be able to express themselves in clear English are being taught political slogans. Children who need to be taught to respect traditional moral values are being taught that they have an inalienable right to be gay"

(October 9, 1987, http://www.margaretthatcher.org/document/106941).

${ }^{6}$ MP Tomothy Brinton: "Is my right hon. Friend aware that the Labour-controlled GLC has spent over $£ 500,000$ on its political magazine The Londoner, over $£ 300,000$ on political campaigns and $£ 220,000$ on minority groups such as the English Collective of Prostitutes, Lesbian Line, and the Teenage Gay Rights Group? Does my right hon. Friend agree that this is a waste of money, particularly when it is combined with roaring rates that are driving industry, jobs and people out of London?". The Prime Minster Thatcher: "My hon. Friend is correct. It is a disgraceful waste of money and a disgraceful imposition of increases on the tax burden, especially for small businesses"

(PM's Questions, November 25, 1982, http://www.margaretthatcher.org/document/105059).

7 Thatcher: "I said that some people, some people, whether from the Church or elsewhere, had spoken out to the effect that morals do matter in AIDS"

(January 29, 1987, http://www.margaretthatcher.org/document/106737),

8 Thatcher: "there was a committee which looked at it and said that if we went on as we are then by the end of the century there would be four million people of the new Commonwealth or Pakistan here. Now, that is an awful lot and I think it means that people are really rather afraid that this country might be rather swamped by people with a 
cultural racism" (Hall 1988a, 146) that defends "Englishness" and "the English feeling 'Great again"', which is one "of the unexpected sources of Thatcherism's popularity" (Hall and Jacques 1989, 132). Thatcherism ideologically combines "the philosophies of tradition, Englishness, respectability, patriarchalism, family, and nation. The most novel aspect of Thatcherism was indeed the very way in which it combined the new doctrines of the free market with some of the traditional emphases of organic Toryism" (Hall 1988b, 39). Thatcherism defends "a narrow, national definition of Englishness" and frequently asks, "Are you one of us?" (Hall 1997, 26).

Thatcher "engineered the fatal coupling of the anti-Labourist, anti-statist, anti-equality, anti-welfare spirit with the revitalized gospel of the free market. Thus the qualitatively new and unstable combination of 'Thatcherism'-organic national patriotism, religion of the free market, competitive individualism in economic matters, authoritarian state in social and political affairs-began to cohere as an alternative social philosophy" (Hall 1988a, 199-200). "The triumph of Thatcherism represented the triumph of an ideology of selfishness and scapegoats" (Hall 1988a, 251).

\section{Raymond Williams: Thatcherism as Plan X}

Raymond Williams (1989, section 5) shares Stuart Hall's analysis that the Left needs a socialism that reaches popular sentiments in order to challenge Thatcherism and that victories of the New Right have to do with the weakness of the Left. In what could be read as an implicit criticism of Hall, Williams ascertains that Thatcherism is successful because it has materialised "a peculiarly hard, authoritarian, anti-intellectual, racist consciousness" that is "endemic in the society" (Williams 1989, 163). He foregrounds that Britain's majority voting system permitted Thatcher's absolute power, although Thatcherism did not have the absolute majority's support. Thatcher won absolute majorities of all MPs in the elections in 1979, 1983 and 1987 with $33.4 \%, 30.8 \%$ and $31.8 \%$ of the eligible votes ${ }^{12}$. In 2015 , David Cameron ob-

different culture and, you know, the British character has done so much for democracy, for law and done so much throughout the world that if there is any fear that it might be swamped people are going to react and be rather hostile to those coming in. So, if you want good race relations, you have got to allay peoples' fears on numbers. [...] we must hold out the clear prospect of an end to immigration because at the moment it is about between 45,000 and 50,000 people coming in a year. Now, I was brought up in a small town, 25,000 . That would be two new towns a year and that is quite a lot. So, we do have to hold out the prospect of an end to immigration except, of course, for compassionate cases. Therefore, we have got to look at the numbers who have a right to come in. [...] We are a British nation with British characteristics. Every country can take some small minorities and in many ways they add to the richness and variety of this country. The moment the minority threatens to become a big one, people get frightened"

(January 27, 1978, http://www.margaretthatcher.org/document/103485).

${ }^{9}$ Thatcher: "Then, there is fraudulent unemployment, that is to say, people who draw benefit while earning money. There is evidence of this in casual occupations like the building industry. It helps explain why at one period the statistics showed 100,000 unemployed in the building industry while builders all over the country complained of a labour shortage. There are the drifters and hippies who draw "welfare" but engage in activities to earn money, legal or illegal. From time to time the Ministry carries out local checks, and suddenly the number of registered unemployed melts away. How many fraudulent unemployed there are at any given time can only be estimated, but they probably account for at least a tenth of the registered unemployed at normal times. We ought to do more about such people, but expanding demand will not turn them into honest men"

(September 5, 1974, http://www.margaretthatcher.org/document/110607).

Thatcher: "There are a few people in America, and in Britain, who have got used to living on welfare and want to go on living on welfare. In other words, you've got people who don't wish to do the very thing on which America is founded-a life of effort on the premise that if you accept freedom you accept the duties that go with it" (April 27, 1992, http://www.margaretthatcher.org/document/111359)

11 Thatcher: "Real incomes per head have risen beyond what anyone dreamed of a generation back; so have education budgets and welfare budgets, so also have delinquency, truancy, vandalism, hooliganism, illiteracy, decline in educational standards. Some secondary schools in our cities are dominated by gangs operating extortion rackets against small children. Teenage pregnancies are rising; so are drunkenness, sexual offences, and crimes of sadism. For the first time in a century and a half, since the great Tory reformer Robert Peel set up the metropolitan police, areas of our cities are becoming unsafe for peaceful citizens by night, and even some by day" (October 19, 1974, http://www.margaretthatcher.org/document/101830)

${ }^{12}$ http://www.politicsresources.net/area/uk/uktable.htm 
tained an absolute majority with $36.9 \%$ of the cast votes. The voter turnout was $66.1 \%$, which means that actually $24.4 \%$ of the eligible votes sufficed for forming a majority government ${ }^{13}$.

In 1983, Raymond Williams spoke in his book Towards 2000 of the emergence of a new politics he called "Plan X": It is competitive, focuses on strategic advantages, fosters deindustrialisation, is patriotic, xenophobic and chauvinist, and advances politics of surveillance and control (Williams and McGuigan 2015, section V). Jim McGuigan argues in the 2015 new edition of this book that Williams described with the concept of Plan $X$ the fusion of neoconservatism and neoliberal economics (Williams and McGuigan 2015, 35). "Thatcherism was a local manifestation" of Plan X (McGuigan 1992, 25). It is, however, unclear why Williams chose the term "Plan X": The use of a variable ("X") communicates uncertainty about the outcomes, which implies non-strategic action on the part of Thatcher. Neoliberalism's outcomes, such as the increase of inequalities, are, however, not arbitrary, but have their roots in this governance model's structure and in capitalism itself.

For Williams, Thatcherism arose from the dislocations caused by the contradictions of deindustrialising British capitalism and the rise of mobile privatisation (Williams 1989, 161-174). New technologies, the welfare state and mass consumption have enabled more flexible, private and individualised lifestyles that enhance the potentials for freedom (of choice, activity, mobility), but at the same time cause insecurity by the deterioration of traditional communities. The Right would have successfully mobilised citizens' fears and aspirations in light of these insecurities and potentials, whereas the Left would have missed the opportunity to connect these changes to "a quite different kind of socialist ideas and socialist language" (Williams 1989, 174).

\section{Bob Jessop: Thatcherism as the Two Nations Strategy}

Bob Jessop et al. $(1988,69)$ argue that Hall's explanation of Thatcherism is an "ideologism" that neglects the economic, political and institutional contexts. Hall (in: Jessop et al. 1988, chapter 5) responds that he did not work out a general explanation of Thatcherism and did not want to claim that it was only an ideological project. He rather stresses that ideology is an important dimensions of Thatcherism. Jessop et al. (1988) conceive Thatcherism as a flexible unity of an accumulation strategy, a state strategy and a hegemonic national-popular ideological and political programme. They situate the rise of Thatcherism in the crisis of the Keynesian welfare state (34), the petty bourgeoisie and small and medium capital's opposition to the welfare state (34), recession, and the British economy's long-term decline (71). Thatcherism would have become popular by flexible switches between promises (e.g. the right to buy one's council flat, tax cuts, etc.) and scapegoating

Jessop et al. characterise Thatcherism as neoliberal strategy consisting of a regime of accumulation that foregrounds the internationalisation of capital, flexible post-Fordist accumulation, financialisation, popular capitalism, the entrepreneurial society; a state strategy consisting of deregulation, privatisation, institutional Darwinism, monetarism, austerity, and authoritarianism; as well as an ideological division into two nations. It is the latter element that Jessop et al. (1988) particularly foreground, which also the book title Thatcherism: A Tale of Two Nations expresses. The key element for Jessop et al. is Thatcherism's strategy of dividing and constructing a struggle between two nations, one part being constructed as "productive" and the other as "parasitic":

"Tory populism is taking the form of a unification of a privileged nation of 'good citizens' and 'hard workers' against a contained and subordinate nation which extends beyond the inner cities and their ethnic minorities to include much of the non-skilled working class outside the South-East. [...] Thatcherism presents an image of social divisions based on a single, vertical cleavage stretching from top to bottom of society which opposes the productive to the parasitic. This opposition between 'two nations' is seen as inherently antagonistic and cannot be transcended through the collectivism of the KWS

\footnotetext{
${ }^{13}$ http://www.politicsresources.net/area/uk/uktable.htm
} 
[Keynesian welfare state]. In general the productive sector is held to comprise those who produce goods and services that can be profitably marketed without the need for state subsidies. The parasitic include not only the various pauper classes (the unemployed, pensioners, the disabled, etc.) but also those whose economic activities in the public or private sectors are unprofitable in terms of capitalist forms of accounting. Only those state employees are excluded whose activities are essential to the minimal nightwatchman role of the state-the police, armed forces, tax gatherers, etc." (Jessop et al. 1988, 87-88).

Thatcherism also uses the division productive/parasitic for dividing between rich/poor, South/North, employed/unemployed, etc. (135). Although Jessop et al. argued that Hall's approach is a form of ideologism and Hall responded that the two nations approach was unconvincing because Thatcherism would not have so much talked about hard work or good citizens, but rather about wealth creators, there are many parallels between the two approaches: Both argue for a complex, multi-dimensional understanding of Thatcherism and agree that economic and social crises alone cannot explain its rise and that therefore the role of an authoritarian state and populist ideology needs to be taken into account. Rather missing from Jessop et al.'s account is the ideology of Englishness and of the greatness of Britain, which reflects the decline of the British Empire. This decline together with political devolution in Scotland, Wales and Northern Ireland, the UK's accession to the EU in 1973, and increased levels of immigration, resulted in a crisis of English identity and the question if these changes should be embraced as an open, multicultural Britain or resisted by English nationalism (Kumar 2003). Although Jessop et al. express scepticism about the authoritarian populism approach and Hall about the two nations approach, the two nations ideology is a form of authoritarian populism that not just has an ideological, but also a political dimension because it can easily be used for arguing for authoritarian state measures.

\section{A Three-Dimensional Model of Thatcherism}

The problem of many enumerative definitions of Thatcherism is that they lack order and a systematic. If we see society as consisting of the three dialectically interlinked realms of the economy, politics and culture (Fuchs 2008, 2014), then a theoretically grounded model of Thatcherism is possible. It includes:

\section{ECONOMY}

- The propagation of private-capitalist ownership combined with the privatisation and commodification of public goods, the public economy and public services (economic organisation),

- Monetarism, keeping inflation low, financialisation of the economy, the fostering of consumer and private household debt and its financialisation (monetary system),

- Wage repression and anti-unionist class struggle (class relations),

\section{POLITICS}

- Relatively unregulated markets favouring self-regulation of companies (state-economy nexus),

- Law and order and surveillance politics (legal system, policing),

- The militarisation of inner and outer defence (defence system)

- The cutting of state expenditures for education, health care, pensions, social affairs and welfare benefits for the weak, ill, disabled, poor and unemployed (social system),

- Regressive taxation, low income and corporation taxes (taxation),

\section{CULTURE}

- Extreme competitive individualism practicing social Darwinism and survival of the fittest (ethics and culture of everyday life), 
- The foregrounding of traditional values and national identity (collective identity).

- Scapegoating and moral panics (ideologies).

Tariq Ali argues that neoliberalism has become a consensus among many political parties. He terms this consensus the extreme centre. The extreme centre "backs austerity measures; it defends surveillance as absolutely necessary to defeat terrorism, without ever asking whit this terrorism is happening" (Ali 2015b, 19). "Throughout the heartlands of capital we have witnessed the convergence of political choices: Republicans and Democrats in the United States, New Labour and Tories in Britain, Socialists and Conservatives in France; the German coalitions, the Scandinavian centre-right and centre-left, and so on" (Ali 2015b, 147).

$A$ in my view more exact characterisation of this hegemonic bloc is that the Centre and the Left have shifted towards the Right so that there is a right-wing consensus, not an extreme centre. Thatcherism and Reagonomics are not over, but exist as versions 2.0 that have quite successfully masked the dialectical contradiction between the Left and the Right while the class contradictions and resulting inequalities have paradoxically at the same time been deepened.

Ali (2015a) says that there were different motivations for the creation of the European Union and that effectively attempts to create a social Europe were fended off so that it became a neoliberal project dominated by "market extremism" (93). In Europe, only Syriza in Greece and Podemos in Spain would forcefully question the neoliberal consensus and struggle for alternatives. The success of the Scottish National Party (SNP) does not predominantly have to do with nationalism, but with decades of never-ending Thatcherite politics in Britain that most Scots oppose and the fact that the SNP is the social democratic party that the Labour Party had long ceased to be. With Jeremy Corbyn becoming its Leader in 2015, the Labour Party has undergone a significant shift to the Left in the political spectrum. This situation forms Cameronism's political context.

\section{Cameronism's Ideology and Politics}

Cameronism is a specific type of Tory ideology and form of politics that has a particular model for organising society, i.e. the economy, the political system, and culture. Cameronism has become a significant topic of research (Finlayson 2007; Kerr, Byrne and Foster 2011; Reyes 2007; Seymour 2010). The situation for such studies has changed by the fact that the Tories formed a majority government in May 2015, which means that any constraints on Cameronism posed by the Liberal Democrats as coalition partner were removed so that a purer form of Cameronist politics became possible.

In order to analyse Cameronism's ideology and policies, I have identified key speeches, interviews and documents that define the Conservatives' agenda under Cameron:

- D1: David Cameron: Speech on the big society. May 23, 2011. https://www.gov.uk/government/speeches/speech-on-the-big-society

- D2: David Cameron: Speech on the fightback after the riots. August 15, 2011. https://www.gov.uk/government/speeches/pms-speech-on-the-fightback-after-the-riots

- D3: David Cameron's welfare speech in full. The Telegraph Online. June 25, 2012. http://www.telegraph.co.uk/news/politics/david-cameron/9354163/David-Cameronswelfare-speech-in-full.html

- D4: David Cameron: EU speech at Bloomberg. January 23, 2013. https://www.gov.uk/government/speeches/eu-speech-at-bloomberg

- D5: David Cameron: Speech on families. August 18, 2014. https://www.gov.uk/government/speeches/david-cameron-on-families

- D6: David Cameron: EU speech. November 28, 2014. http://www.bbc.co.uk/news/ukpolitics-30250299

- D7: David Cameron calls on Ed Miliband to rule out SNP deal. BBC Online. March 7, 2015. http://www.bbc.co.uk/news/uk-politics-31780935 
- D8: David Cameron: Speech at the European Council. March 20, 2015. https://www.gov.uk/government/speeches/european-council-march-2015-pre-councilpress-conference

- D9: Theresa May: A new partnership to defeat extremism. March 23, 2015. https://www.gov.uk/government/speeches/a-stronger-britain-built-on-our-values

- D10: Cameron accuses Ball of 'appaling' comment over 2010 'no money' note. The Guardian Online. April 16, 2015. http://www.theguardian.com/politics/2015/apr/16/david-cameron-ed-balls-no-money-note

- D11: The Conservative Party Manifesto 2015, https://www.conservatives.com/Manifesto

- D12: David Cameron: Election victory speech. May 8, 2015 https://www.gov.uk/government/speeches/election-2015-prime-ministers-speech

- D13: David Cameron lays out plans for 'blue-collar Conservatism' as cabinet meets. The Guardian Online, May 12, 2015. http://www.theguardian.com/politics/2015/may/12/david-cameron-sets-out-priorities-asconservative-cabinet-meets-for-first-time

- D14: David Cameron and Theresa May: Counter-Extremism Bill-National Security Council meeting. May 13, 2015.

https://www.gov.uk/government/news/counter-extremism-bill-national-security-councilmeeting

- D15: David Cameron: Speech on immigration. May 21, 2015. https://www.gov.uk/government/speeches/pm-speech-on-immigration

- D16: Prime Minister's Questions. January 21, 2015. http://www.publications.parliament.uk/pa/cm201415/cmhansrd/cm150121/debtext/150121 -0001.htm\#15012165000005

- D17: Prime Minister's Questions. February 4, 2015. http://www.publications.parliament.uk/pa/cm201415/cmhansrd/cm150204/debtext/150204 -0001.htm\#15020466000005

- D18: Prime Minister's Questions. March 25, 2015. http://www.publications.parliament.uk/pa/cm201415/cmhansrd/cm150325/debtext/150325 -0001.htm\#15032574000007

In the analysis that follows, I predominantly use the method of immanent ideology critique (Antonio 1981) that compares discursive claims to empirical reality with the help of statistics and studies. In case the claims and reality do not corresponds, then there are indications that the discourse is an ideology that tries to distort the representation of reality in order to justify, uphold and advance specific interests and power relations. We can understand an ideology in this context as a system of "thoughts, practices, ideas, words, concepts, phrases, sentences, texts, belief systems, meanings, representations, artefacts, institutions, systems, or combinations thereof that represent and justify one group's or individual's power, domination, or exploitation of other groups or individuals by misrepresenting, one-dimensionally presenting, or distorting reality in symbolic representations" (Fuchs 2015, 78-79).

\subsection{Cameronism's Economic Dimension}

\section{The Ideology of Responsible Economic Management}

Concerning the economic organisation of society, Cameronism argues that Labour tends to mismanage the British economy and that the Tories have the skills and competence to fix the broken economy, put it back on track and to put the unemployed into work. The Conservatives continuously presented Ed Miliband and the Labour Party in the parliamentary period 2005-2010 as a tax and spend-party not able to manage the economy. In their 2015 Election Manifesto, the Conservatives also featured this message: 
"More borrowing-and the extra debt interest that it brings-means there is less money to spend on schools and hospitals. More spending means higher taxes for hardworking people, and interest rates that are higher than they otherwise would bepunishing homeowners, hurting businesses, costing jobs. [...] So you face a clear choice: Economic competence, with David Cameron as Prime Minister, following through on our long-term economic plan. Or economic chaos under Labour, with higher taxes, more debt and no plan to fix our public finances, create jobs or build a more secure economy" (D11, 8).

Cameron communicated the same discourse of Labour's economic chaos and the Conservatives' responsible economic management week by week in the live-broadcast Prime Minister's Questions:

"The most vital election in a generation is coming, and people can see the choice: a Labour party that is anti-enterprise, anti-business and that is falling apart under scrutiny, and a Conservative party turning this country around. That is the choice: competence from us, chaos from them" (D17)

"Under this Government, we have got over 30 million people in work, we have got the lowest rate of young people claiming unemployment benefit since the 1970s, long-term unemployment is down, and women's unemployment is down. We are getting the country back to work. In terms of living standards, we have raised to $£ 10,000$ the amount of money people can earn before they start paying taxes, and people who are in work are seeing their pay go up by $4 \%$. If we had listened to the right hon. Gentleman [Ed Miliband], none of these things would have happened. If we had listened to Labour, it would be more borrowing, more spending, more debt: all the things that got us into a mess in the first place" (D16).

"This is a country where unemployment is falling; the economy is growing; the deficit is coming down; in our NHS, the operations are going up; there are more good school places for our children; living standards are rising; inflation is at zero; and there are record numbers in work-all of this could be put at risk by Labour. That is the choice in 43 days' time: competence and a long-term plan that is delivering, instead of the chaos of economic crisis from Labour" (D18)

In the 2015 campaign, David Cameron in order to symbolically underpin the message of economic chaos caused by the Labour Party presented a note by Liam Byrne, Gordon Brown's Chief Secretary to the Treasury, that said: "I'm afraid there's no money left". Cameron: "We had to make some very very difficult decisions to get this country back on track. That note that said there is no money left was referring to the fact that our budget deficit was forecast to be bigger than the budget deficit in Greece when I became prime minister" (D10). Labour said the money had not run out and that the paper left in the Treasury was just a piece of humour.

The Conservatives' message on economic organisation and the public household is based on an us/them division: the Conservatives' responsible management VS. Labour's economic chaos.

\section{The Budget: "Responsible Management", Tax Cuts, Social Security Cuts}

In absolute terms, the UK national debt more than doubled in the years from 2009 until 2015 from $£ 0.62$ trillion to $£ 1.36$ trillion (data source: ukpublicspending.co.uk). This means an increase from $51.97 \%$ of the GDP in 2008 to $78.76 \%$ in 2015 (data source: ukpublicspending.co.uk). The average annual growth of the national debt was $3.8 \%$ of the GDP in the years 2010-2015 of the Cameron/Clegg government (data source: own calculations based on ukpublicspending.co.uk) compared to an average of $0.8 \%$ under the Labour governments 
1997-2009, 2.4\% under John Major's governments 1991-1996, and $-1.7 \%$ under Thatcher 1979-1990.

There was an increase of national debt from $38.9 \%$ of the GDP in 2008 to $52.0 \%$ in 2009 , which signifies the British state's $£ 500$ billion bailout of banks in the financial crisis. Under Cameron and Clegg, the debt, however, further increased to $80.9 \%$ of the GDP in 2014 . On average, the Conservative government's total spending was $38.6 \%$ of the GDP under John Major in the years 1991-1996 and 40.9\% in the Thatcher years 1979-1990. This average decreased to $38.0 \%$ of the GDP under the Labour governments in the years 1997-2009 and increased to $42.3 \%$ under the Conservative/Lib Dem coalition in the years 2010-2015.

The British economy has since the start of the world economic crisis 2008 been in a recession. The GDP shrank by $0.3 \%$ in 2008 and by $4.3 \%$ in 2009 (data source: ONS). The average growth in the years $2011-2014$ was $1.7 \%$ compared to $3.0 \%$ in the years $2000-2007$ (data source: ONS). In order to maintain equality levels and living standards, it is necessary to in such a situation increase general taxation, especially of upper incomes and large companies. The Tory/Lib Dem government did exactly the opposite: It reduced the main rate of corporation tax as well as the upper income tax band.

While income and capital gains tax revenue was on average $13.7 \%$ of the GDP during the Labour governments 1997-2009, it decreased to $12.4 \%$ under the Tory/Lib Dem government in the years 2010-2015 (data source: ukpublicspending.co.uk). The top-rate of income tax was around $90 \%$ in the 1950 s and 1960 s. Thatcher reduced it first from $83 \%$ to $60 \%$ and then to $40 \%$. In 2010, the Labour government under Gordon Brown introduced a top income tax band of $50 \%$ for all income higher than $£ 150,000$. The Tory/Lib Dem government reduced this tax band to $45 \%{ }^{14}$. The 2015 Conservative Election Manifesto announced that the Tories wanted to raise the $40 \%$ threshold from around $£ 32,000$ in tax year $2015 / 2016$ to $£ 50,000$ (D11, 25).

The rise of neoliberalism has brought about a drastic long-term decrease of business and other taxes in the UK: Their share in GDP decreased from on average $6.7 \%$ in the years $1970-1978$ to $6.4 \%$ in $1979-1990$ (Thatcher), $3.5 \%$ in 1991-1996 (Major), $2.8 \%$ in $1997-2009$ (Blair/Brown), and 2.8\% in 2010-2015 (Cameron/Clegg) (data source: ukpublicspending.co.uk). In 2015, these taxes reached the lowest level since 1947 , namely $2.45 \%$ of the GDP (data source: ukpublicspending.co.uk). The main rate of corporation tax was at a level of $40 \%$ in 1965 . Thatcher reduced it to $30 \%$, the Labour government from $30 \%$ to $28 \%$ in 2007, and the Tory/Lib Dem government subsequently to $26 \%$ (2011), 24\% (2012), 23\% (2013), 21\% (2014) and 20\% (2015) $)^{15}$.

The Conservatives' economic strategy is to cut taxes for the rich, the middle class and companies. In the situation of economic crisis, the result has been an increase of national debt.

"The period since the financial crisis and associated recession struck has seen a dramatic deterioration in the UK's public finances. [...] In March 2008, the Treasury forecast that borrowing would decline from $2.9 \%$ in $2008-09$ to $1.3 \%$ of national income in 2012-13, but instead it climbed to over $10 \%$ of national income (the highest level seen in the UK since the Second World War). This, coupled with the decline in national income, pushed up public sector net debt measured as a share of national income substantially" (Institute for Fiscal Studies 2015, 11).

In terms of taxation and the social system, Cameronism favours low taxes in general and particular for corporations, the rich and the middle class combined with cuts of welfare and the social system. The 2015 Conservative Party Election Manifesto announced that a Conservative government "will find $£ 12$ billion from welfare savings" (D11, 8). The welfare budget was around $£ 110-120$ billion in the years 2010-2015 (date source: http://www.ukpublicspending.co.uk). Cuts of $£ 12$ billion mean a massive reduction of more

\footnotetext{
${ }^{14} \mathrm{http}$ ://en.wikipedia.org/wiki/Taxation in the United Kingdom\#Income tax

15 http://en.wikipedia.org/wiki/United_Kingdom_corporation_tax\#cite_note-Budget_2007-68
} 
than $10 \%$. The welfare budget includes care for the elderly, sick and disabled, public sector pensions, unemployed benefits, tax credits for people on low incomes, housing benefits, and childcare. Reductions hit society's poorest and weakest.

\section{Privatisation and Financialisation}

So the Tories' claims do not live up to reality, but admittedly seem to have in the 2015 General Election ideologically convinced a significant number of voters. The Tory/Lib Dem government's economic strategy also included privatisations, such as e.g. of the Royal Mail, Eurostar International, or East Coast trains. It also advanced Right to Buy-discounts that allow council flat tenants to become private owners. The Tories' 2015 Election Manifesto announced a further extension of the scheme. The Right to Buy scheme was introduced by Thatcher in 1980 and has resulted in a subsequent privatisation of council housing ${ }^{16}$, which has also spurred the financialisation of the housing market. If collective forms of ownership of housing (council houses, housing associations, housing co-operatives s) disappear, it becomes under conditions of neoliberal deregulation easier for private landlords to increase rents. The Health and Social Care Act 2012 enabled the access of private health care providers to the National Health Service so that private-public-partnerships can foster the NHS's piecemeal privatisation. The tripling of university tuition fees to $£ 9,000$ p.a. not just created a generation of indebted young people, but also advanced the commodification of higher education.

\section{Labour Market Policies: “Hard Work”, Meritocracy and Precarity}

The Tories pride themselves to "get people into work". The key question is however what quality jobs have. Unemployment in the UK has indeed fallen from a level of $8.4 \%$ in September-November 2011 to $5.5 \%$ in January-March 2015 (data source: ONS). According to estimations, a vast share of the created jobs is low paid, insecure, casual work: Zero-hours contracts have increased within a year from 600000 to 700000 in $2015^{17} .31 \%$ of the jobs created since 2010 were in self-employment, where average earnings have fallen by $22 \%$ since $2008 / 2009^{18}$. Of the almost 1.1 million employed and self-employed jobs created between 2008 and 2014, around two thirds were part-time jobs ${ }^{19}$.

The question is if it can be considered responsible management of the economy if a majority of new jobs is precarious labour. The hard work ideology also obscures the fact that technological development changes the conditions of work. New technologies and rising productivity make it possible to automate unpleasant forms of work. As result of long-time automation, the general working hours could be reduced. Cameronism masks the contradictions of labour time and automation in capitalist society.

Cameronism is an ideology of hard labour: It argues that it works hard to manage the economy by fiscal austerity, reducing public spending and cutting taxes and that it does all to advance the interests of hard working Britons by reducing their taxes, immigration and welfare abuse:

"Under Labour, those who worked hard found more and more of their earnings taken away in tax to support a welfare system that allowed, and even encouraged, people to choose benefits when they could be earning a living. This sent out terrible signals: if

\footnotetext{
${ }^{16}$ http://en.wikipedia.org/wiki/Right_to_Buy

17 Almost 700,000 people in UK have zero-hours contracts as main job. The Guardian Online, February 25, 2015. http://www.theguardian.com/uk-news/2015/feb/25/zero-hours-contract-rise-staff-figures

18 TUC: Zero-hours contracts just the tip of the iceberg for low-paid and insecure jobs, says the TUC. April 26, 2015.

https://www.tuc.org.uk/economic-issues/zero-hours-contracts-just-tip-iceberg-low-paid-and-insecure-jobs-says-tuc ${ }^{19}$ TUC: Only one in every forty net jobs since the recession is for a full-time employee, says TUC. November 12 , 2014.

https://www.tuc.org.uk/economic-issues/labour-market-and-economic-reports/only-one-every-forty-net-jobsrecession-full-time
} 
you did the right thing, you were penalised-and if you did the wrong thing, you were rewarded, with the unfairness of it all infuriating hardworking people" (D11, 25).

"And for that person intent on ripping off the system, we are saying-we will not let you live off the hard work of others. Tough sanctions. Tougher limits. In short we're building a system that matches effort with reward instead of a system that rewards those who make no effort" (D1).

Also in his election victory speech 2015, David Cameron appealed to hard working and lawabiding British citizens:

"we can make Britain a place where a good life is in reach for everyone who is willing to work and do the right thing. Our manifesto is a manifesto for working people, and as a majority government we will be able to deliver all of it" (D12).

"helping 30 million people cope with the cost of living by cutting their taxes; building homes that people are able to buy and own; creating millions more jobs that give people the chance of a better future" (D12).

Cameron's strategy is to also appeal to the working class by what he and others term "bluecollar Conservatism". Cameron:

"The pundits might call it 'blue-collar Conservatism', others being on the side of hardworking taxpayers. I call it being the real party for working people: giving everyone in our country the chance to get on, with the dignity of a job, the pride of a paycheque, a home of their own and the security and peace of mind that comes from being able to support a family" (D13).

The hard work-ideology is an element of populism that aims to reach out to everyday people's popular desire for leading a good life. It promises to fulfil their desires by making other people's lives more miserable. Tax cuts predominantly benefit the middle and upper class, whereas Tory/Lib Dem measures such as the tripling of higher education fees to $£ 9,000$ per year, welfare cuts and the increase of VAT from $17.5 \%$ to $20 \%$, predominantly hit the lower income group.

The hard work ideology is the expression of a meritocratic discourse that argues that there is a "ladder of opportunity for all to climb" (Littler 2013, 54). Hard labour and performance are presented as the means to reach the upper end of this ladder. The problem is that meritocracy is competitive-individualist, fosters inequality, ideologically curtails inequality, and disregards institutionalised power structures (Littler 2013, Seymour 2010). The hard work ideology has as outside those who are presented as parasitic, unproductive and "scroungers", against whom scapegoating and coercive measures are easy at hand. Thatcherism and Cameronism's meritocratic ideology sends out a clear social Darwinist message: "You can make it if you work hard. And if you succeed, a low tax regime will reward you. If not, then nobody but you is to blame. Don't expect mother and brother welfare state to help you! There will be no love lost! The state will coerce you!".

Cameronism's ideological trick is to dissimulate attention from the strengthening of the interests of the rich and corporations, the class conflict and its social inequality, and the power of capital and finance by appealing via blue-collar Conservatism to other (lower economic) groups' aspirations to own and purchase private homes and to class mobility, i.e. the desire to master the transition to the middle, upper-middle or upper-class. Cameronism promises the actual realisation of these desires by arguing that the hurdle for achieving it are immigrants, welfare recipients, the unemployed, the poor, gangs and criminals, terrorists, and the European Union. Blue-collar Conservatism uses the language of decentralised socialism, its stress on civil society, voluntary associations, mutualism and co-operativism. It combines this language with neoliberal anti-statism in order to appeal to citizens' desire for self- 
governance. The results of this hidden form of privatisation are, however, higher social risks and a tendency for increased inequality.

\section{Trade Union Policies}

Blue-collar Conservatism is also contradicted by the way the Tories want to treat labour unions. Long-term stagnation of wage increases and social cuts resulted in a series of strikes by primary and secondary school teachers, health care workers, higher education teachers, public transport workers under the Tory/LibDem government. Reminiscent of Thatcher's antiunionism, the 2015 Conservative Election Manifesto argued:

"We will protect you from disruptive and undemocratic strike action: Strikes should only ever be the result of a clear, positive decision based on a ballot in which at least half the workforce has voted This turnout threshold will be an important and fair step to rebalance the interests of employers, employees, the public and the rights of trade unions. We will, in addition, tackle the disproportionate impact of strikes in essential public services by introducing a tougher threshold in health, education, fire and transport. Industrial action in these essential services would require the support of at least 40 per cent of all those entitled to take part in strike ballots-as well as a majority of those who actually turn out to vote" (D11, 18-19).

The Tories want to make it more difficult for unions to call for strikes. When they speak of "rebalancing interests", they mean the weakening of workers who strike for higher pay and therefore the strengthening of capital's power. This measure is strategically planned in an intelligent manner because it focuses on the public service sector and appeals to the average worker's fear of not reaching his workplace, not being able to send her kids to school or not being able to reach a hospital in an emergency. It aims to pit workers in the private sector against those in the public sector. It may, however, not be a surprise if going down this road results in further limits on strikes also in the private sector.

\subsection{Cameronism's Political Dimension}

\section{Euroscepticism}

Right-wing populism is one answer to the prolonged capitalist crisis. It argues that "it is EU policies which have led to austerity and hurt the poor, and second, that the free movement of labour from EU countries with low wages and high unemployment makes conditions much worse" (Ali 2015a, 102-103). This combination of arguments is also typical for Cameronism. Cameronism is politically a specific form of Euroscepticism that argues that the European Union limits British business interests by too many rules and that its bureaucratic centralism questions British national sovereignty. In the EU speech, in which he announced a referendum about Britain's status in Europe, David Cameron argued for example:

"excessive regulation is not some external plague that's been visited on our businesses. [...] if Europe today accounts for just over 7 per cent of the world's population, produces around 25 per cent of global GDP and has to finance 50 per cent of global social spending, then it's obvious that it will have to work very hard to maintain its prosperity and way of life.[...] Third, there is a growing frustration that the EU is seen as something that is done to people rather than acting on their behalf. [...] I want us to be pushing to exempt Europe's smallest entrepreneurial companies from more EU Directives. [...] The EU must be able to act with the speed and flexibility of a network, not the cumbersome rigidity of a bloc. [...] People [...] resent the interference in our national life by what they see as unnecessary rules and regulation" (D4). 
Cameron portrays the EU as limiting British capitalism with too many rules centrally made in Brussels. He thinks that it too much tames neoliberalism. Cameronism wants a neoliberalism that is purer than the one the EU advances. It wants a European Union that is a pure economic union for the free trade of goods and services, that is not a political and social union, and that does not enable the free movement of labour forces:

"We have the character of an island nation - independent, forthright, passionate in defence of our sovereignty [...] There is not, in my view, a single European demos. It is national parliaments, which are, and will remain, the true source of real democratic legitimacy and accountability in the EU. [...] People feel that the EU is heading in a direction that they never signed up to. They resent the interference in our national life by what they see as unnecessary rules and regulation. And they wonder what the point of it all is. Put simply, many ask 'why can't we just have what we voted to join - a common market?"' (D4).

\section{Law and Order Politics}

Concerning policing and the legal system, Cameronism stands for a strong state that implements law and order politics. As a consequence of developments such as $9 / 11$, the July 2005 underground and bus bombings in London, the 2013 murder of Lee Rigby, the 2015 Paris attacks in Paris attacks, or the 2016 Brussels bombings, Cameronism considers Islamic fundamentalism as the main political and security threat. The question is how to best deal with such unsettling phenomena that have complex causes. Cameronism's answer is to build a security and surveillance state. In May 2015, the newly elected Conservative majority government announced the introduction of Banning Orders, Extremism Disruption Orders, the closure of extremist premises, and the introduction of Ofcom's power to shut down channels broadcasting extremist content by Ofcom (D14).

The Conservative Party Manifesto 2015 described these measures the following way:

"We will outlaw groups that foment hate with the introduction of new Banning Orders for extremist organisations These could be applied to dangerous organisations that fall short of the existing thresholds for proscription under terrorism legislation To restrict the harmful activities of extremist individuals, we will create new Extremism Disruption Orders These new powers might, for instance, prevent those who are seeking to radicalise young British people online from using the internet or communicating via social media. [...] We will strengthen Ofcom's role so that tough measures can be taken against channels that broadcast extremist content" (D11, 65).

The UK Home Secretary Theresa May characterised the Tories' strategy the following way:

"This strategy aims to tackle the whole spectrum of extremism, violent and non-violent, ideological and non-ideological, Islamist and neo-Nazi-hate and fear in all their forms. [...] we must form a new and real partnership between individual people, families, local communities, internet companies, government and civil society as a whole to defeat the extremists. [...] The extremists have no vision for Britain that can sustain the dreams and ambitions of its people. Theirs is a negative, depressing and in fact absurd view of the world - and it is one we know that in the end we can expose and defeat. [...] extremism can take many forms. It can be ideological, or it can be driven by social and cultural norms that are contrary to British values and quite simply unacceptable. We have been clear all along that the Government's counter-extremism strategy must seek to defeat extremism in all its forms, but it's obvious from the evidence that the most serious and widespread form of extremism we need to confront is Islamist extremism. [...] We know there is a link between non-violent extremism and violent extremism. [...] We 
will work with our international allies and seek a partnership with social media companies and communication service providers to deal with extremist content online" (D9).

The deviancy-amplification-spiral is a well-described mechanism in criminology:

A "moral discourse" that collective demonises "the perceived wrong-doers as a source of moral decline and social disintegration [...] may also result in the target group feeing increasingly alienated, particularly when-as often happens-politicians and other 'opinion leaders' enter the fray, demanding tougher action to control and punish the 'deviants' [...] Such widespread condemnation may lead the group to feel more persecuted and marginalized, resulting in an increase in their deviant activity [...] The continuing deviancy results in greater police attention, more arrests and further media coverage" (Jewkes 2011, 77, 79).

A deviancy amplification spiral can be the outcome. The deviancy amplification spiral means that building a surveillance state could actually backfire and intensify terrorism and fundamentalism. In a BBC 4 interview with Theresa May, moderator John Humphrys pointed out the difficulty of legally drawing the border between what is considered to be extremist or not and that the criterion that May advances, namely if British values are respected, is woolly because there are different understandings of it depending if one is a Conservative or not ${ }^{20}$. The concern many people have is not just that a Cameronist surveillance and security state limits freedom of speech and tends to become a totalitarian state that defines criticisms of Cameronism and neoliberalism as extremist and thereby exerts repression against oppositional forces, but that it is counter-productive and radicalises people, who feel scapegoated and controlled by the new forms of state control.

The very language of how Cameronism addresses actual or potential Islamic fundamentalists is divisive. It tends to put British people against Muslims and thereby risks initiating deviancy-amplification-spirals among non-fundamentalist Muslims: "The game is up. We will no longer tolerate your behaviour. We will expose your hateful beliefs for what they are. Where you seek to spread hate, we will disrupt you. Where you break the law, we will prosecute you. Where you seek to divide us, we will stand united. And together, we will defeat you" (D9).

\subsection{Cameronism's Cultural Dimension}

\section{The Culture of Competitive and Possessive Individualism}

One cultural effect of Cameronism is that the rich and those on upper and middle incomes are doing well, but the social risks and inequality are high, and the competition in social upwards and downwards mobility increases. In class societies, there is just a limited number of people who can be on the top of the social hierarchy. Everyone wants to be there and a lot aspire to make it, but only some succeed. The result is a culture of extreme competitive and possessive individualism that lacks social and community spirit. Thatcherite culture is all about individual performance and achievement, involving high risks, high possible gains and possible losses. The culture of strategic competitive individualism results in high levels of inequality. Income inequality measured by the Gini coefficient has since the rise of Thatcherism been continuously at relatively high levels above $30 \%$, whereas in more social democratic countries such as Sweden, Norway and Finland it has at the same time been at a rate between 20\%-25\% (data source: Eurostat).

British society under Cameronism also tends to become more unequal and individualised by reducing taxes for the middle and upper classes so that collective public service provision funded by taxes becomes ever more difficult and private services are put on the agenda, which also means unequal access depending on income levels. The UK Gini coefficient fell

\footnotetext{
${ }^{20}$ BBC 4 Today. May 13, 2015. https://www.youtube.com/watch?v=tpd-aUgx5FI
} 
from $36 \%$ to $34 \%$ in 2014 because "real earnings fell sharply while benefits entitlements remained relatively stable" (Institute for Fiscal Studies 2014, 3). So the cause of this drop is not that people are doing better, but that the general level of wealth has fallen so that slightly decreasing (but still very large) inequality at the same time means an increase of deprivation and wealth deterioration. Taking housing costs into account, the level of absolute poverty increased by 600,000 individuals in Britain from a rate of $22.6 \%$ in $2011 / 12$ to $23.2 \%$ in 2012/13, which means an absolute value of 14.6 million (Institute for Fiscal Studies 2014, 60 ). There has been a clear increase from a level of around $20 \%$ before the Tory/Lib Dem government came to power (ibid.). In the age group 22-30, total income fell by $12 \%$ from 2007 to 2013 (Institute for Fiscal Studies 2014, 91) and unemployment increased from 18.0\% to above $20 \%(109)$. The unemployment rate of those aged $15-24$ has increased from $15.1 \%$ in 2007 to $21.7 \%$ in 2013 (data source: Eurostat).

\section{English Nationalism and the Decline of the British Empire}

Cameronism appeals to the idea of a unified British nation, which is not just an expression of nationalism, but also reflects the fear that Scotland (and subsequently other parts of the UK such as Wales, Northern Ireland, London) could become independent: "we will govern as a party of one nation, one United Kingdom. That means ensuring this recovery reaches all parts of our country: from north to south, from east to west [...] And of course, it means bringing together the different nations of our United Kingdom" (D12).

It is a paradox that the Tories criticise the EU's central power, but fear the same argument when it is made by the SNP about Westminster's central control of the UK. It is a cultural contradiction that Cameronism and Thatcherism appeal to unity in terms of the nation, cultural and morality, which given Britain's actual diversity is just an imagined community, but at the same time destroys the one achievement of the labour movement that has allowed some basic unity in terms of social cohesion, namely the social system and the welfare state.

Britain's geo-political contradictions mean interesting times full of challenges and risks. In the 2015 electoral campaign, Cameron tried to argue that voting for Labour means strengthening the SNP and thereby risks to result in Scottish independence: "You could end up with an alliance between the people who want to bankrupt Britain and the people who want to break up Britain" (D7). Cameron in his 2015 election victory speech also appealed to Britons' nationalist sentiment of being an empire of global relevance: "Together we can make Great Britain greater still" (D12).

The $20^{\text {th }}$ century saw the decline of the British Empire. The United Kingdom lost political control over countries such as Cyprus, Egypt, Ghana, Hong Kong, India, Jamaica, Kenya, Malta, Nigeria, Pakistan, Rhodesia (Zimbabwe), Sudan, or Uganda ${ }^{21}$. This shrinking of British imperial power may be one of the reasons that explain British Conservatism's scepticism towards the European Union, in which Britain faces the threat of having to concede political influence to others, especially Germany and France. British politics has mostly looked up to and stood with its big brother overseas-the United State or what Thatcher called in her 1988 Bruge speech ${ }^{22}$ the "Europe on the other side of the Atlantic".

Aligning itself with the global superpower of the US may have given Thatcherism, Blairism and Cameronism and popular sentiments much more an imperial feeling that consoles over the British Empire's decline than is possible by a defence of Britain as active part of the European Union. Britain is in a "post-imperial crisis" (Gifford 2014, 28), a crisis of its national identity that poses the question of how the country redefines itself.

Thatcherite Europscepticism aimed at "resurrecting and recreating British imagined communities" (Gifford 2014, 28). Thatcherism assumes that "the world should move inexorably towards a universal civilisation modelled on US free market capitalism", which is why it favours "Anglo-American nationalism" (Gifford 2014, 82) and "an Anglo-American neo-liberal

\footnotetext{
${ }^{21}$ For details, see: http://en.wikipedia.org/wiki/Territorial_evolution_of the British_Empire

22 https://www.youtube.com/watch?v=wkRwMFy0CVM
} 
project" (90) over a European identity. Thatcher argued that the roots of America's uniqueness "are essentially English" (cited in: Gifford 2014, 82).

\section{Conservative Moral Values}

Cameronism not just has a stress on English and British national identity, but also on conservative family values. It explains social problems as being moral problems that result from a lack of morality, authority, discipline, and the deterioration of families and as a consequence calls for the strengthening of authority, traditions, law and order, and control. Cameronism neglects the political economy of capitalism, patriarchy and racism in explaining social problems and reduces them to moral issues.

"And so for someone from my political viewpoint who believes in building a stronger society from the bottom up, there is no better place to start than with family. As Ferdinand Mount argued in The Subversive Family, all those in history who have wanted to remake society altogether-whether on the extreme left or the extreme right-have tried to destroy the family. [...] Whether it's tackling crime and anti-social behaviour or debt and drug addiction; whether it's dealing with welfare dependency or improving education outcomes-whatever the social issue we want to grasp-the answer should always begin with family" (D5).

It should also be mentioned that in some respect Cameron has been more liberal than Thatcher in family politics. The Lib Dems have together with the Tories taken the initiative for a bill that introduced same sex civil partnerships. It was passed in 2013. Whereas Thatcher outlawed the positive discussion of homosexuality in schools and tended to view homosexuality negatively, there are no homophobic quotations or policies on record for David Cameron.

After the 2011 London riots, Cameron argued that the riots resulted from moral collapse and that the only solution could be disciplining young people by family authority, law and order, and the labour market:

"Do we have the determination to confront the slow-motion moral collapse that has taken place in parts of our country these past few generations? [...] Children without fathers. Schools without discipline. Reward without effort. Crime without punishment. Rights without responsibilities. Communities without control. Some of the worst aspects of human nature tolerated, indulged-sometimes even incentivised-by a state and its agencies that in parts have become literally de-moralised. [...] First and foremost, we need a security fight-back. [...] Families matter. [...] I want us to look at toughening up the conditions for those who are out of work and receiving benefit... and speeding up our efforts to get all those who can work back to work. Work is at the heart of a responsible society. So getting more of our young people into jobs, or up and running in their own businesses is a critical part of how we strengthen responsibility in our society" (D2).

\section{The Ideology of Scapegoating}

Last, but not least, Cameronism is also an ideological project that constructs scapegoats, especially migrant workers, Eastern and Southern Europeans, welfare recipients, the unemployed, gangs, people of colour and of Muslim religion, for explaining social problems and advancing law and order politics. It presents migrants, the East and the South as economic problems that destroy social cohesion, public services and jobs:

"if you have uncontrolled immigration, you have uncontrolled pressure on public services. And that raises basic issues of fairness. Uncontrolled immigration can damage our labour market and push down wages. And working people want a government that 
is on their side. Uncontrolled immigration means too many people entering the UK legally but staying illegally. And people are fed up with a system that allows those who are not meant to be in our country to remain here" (D15).

"But I am not alone in arguing to change the system or wanting to allay those concerns, here and in Europe, that under the free movement rules, national welfare systems can provide an unintended additional incentive for large migratory movements" (D15).

"Now the uncertainty in the eurozone is in stark contrast to how we are turning the UK economy around. Five years ago, when I came to my first European Council, Britain's economy was close to the edge: a $10 \%$ budget deficit, low growth, high unemployment. Five years on I can report 1.89 million more people in work; the fastest growth of any major Western economy; the deficit cut in half; and our national debt falling as a share of our GDP. We've created more jobs in the UK than the rest of Europe put together" (D8).

"Often the people who have these [liberal] views [on immigration] are those who have no direct experience of the impact of high levels of migration. They have never waited on a social housing list or found that their child's classroom is overcrowded or felt that their community has changed too fast. [...] It is not wrong to express concern about the scale of people coming into the country. [...] People want Government to have control over the numbers of people coming here and the circumstances in which they come, both from around the world and from within the European Union. [...] there was the decision by the last Government not to impose transitional controls on the eight new countries which entered the EU in 2004. With their economies considerably poorer than ours-and with almost every other EU country opting to keep controls-it made the UK a uniquely attractive destination for the citizens of those countries. [...] In some areas, the number of migrants we are seeing is far higher than our local authorities, our schools and our hospitals can cope with. [...] So many people, so fast, is placing real burdens on our public services. [...] And there is pressure on social housing that cannot be met. [...] My objective is simple: to make our immigration system fairer and reduce the current exceptionally high level of migration from within the EU into the UK" (D6).

Comparing the UK to Greece, Cameron's logic implies that the Southern European country is parasitic: "I think the Greek situation is entirely different; we're not members of the eurozone, we haven't made a whole set of promises about our economy and we're not trying to borrow money off anybody" (D8).

Cameronism considers welfare recipients a general problem. It argues that they are used to a passive culture of receiving that limits their spirit for entrepreneurialism. It would be unfair that others pay for them. Cameronism blames individual failures, laziness, passivity, and unwillingness, and therefore tends to oppose social support. It ignores the structural conditions of inequality, discrimination and exclusion:

The welfare system "has sent out some incredibly damaging signals. That it pays not to work. It gave us millions of working-age people sitting at home on benefits even before the recession hit. It created a culture of entitlement. And it has led to huge resentment amongst those who pay into the system, because they feel that what they're having to work hard for, others are getting without having to put in the effort" (D3).

Cameronism combines scapegoating with "blue collar Conservatism" in order to argue that immigrants and welfare recipients harm hard-working Britons:

"I said on the steps of Downing Street we would be a 'one nation' party. That means governing for every single person in Britain: for the mum worrying about her child get- 
ting a school place; for the pensioner fearing he won't get the hospital appointment he needs; for the Asian family whose business is being undercut by illegal traders; for the young couple praying that someone won't jump ahead of them on the housing list and yes-for the migrants trafficked here to live in appalling conditions on pitiful wages. We are for them. We are for working people. For them, we will control immigration" (D15).

Cameronism blames immigrants and welfare recipients for the housing crisis, poor educational, and health services. When discussing this issue, Cameron does not at all analyse the financialisation of the housing market, the privatisation of council housing that Cameron just like Thatcher enforced in the form of a "right to buy", and the commercial pressures on education, the NHS, and other public services. The fusion of anti-Europeanism and antiimmigration sentiments aims not just at fostering a pure form of right-wing politics, but at the same time wants to sell this ideology to working people as representing their true interest. The logic is simple: "The problem are European bureaucracy and European and nonEuropean migrant workers. If we fight them, then your, the British people's, situation will be better than it is now". Cameronism appeals to English nationalist sentiments, the fetishism of hard labour, and racist prejudices.

Cameronism as ideology makes use of a typical ideological strategy: It pits a constructed "us" against a constructed "them". Teun van Dijk (2011) has proposed a scheme called the Ideological Square for the analysis of ideologies. Cameronism makes especially use of two common ideological argumentation strategies in this model: It emphasises positive things about "Us" (the in-group that is law-abiding, respects British values, works hard, etc.) and negative things about "Them". The construction of an abstract "Us" consisting of hardworking, aspirational, entrepreneurial people was already, as Fairclough, Mulderrig and Wodak (2011) show, an important element in Thatcher's speeches. Thatcherism as ideological project combines different discourses such as conservatism, liberal economics, individual entrepreneurialism, authoritarianism, solidarity, and Britishness. It speaks to the "'the people' as a political community" and stresses the British character as collective identity (370). Thatcherism hides that those thriving are "mainly the transnational corporations" (371). Michael Billig argues that the "us" (the national community)/"them" (the foreigners, other nations)-divide is characteristic of all nationalism: "There can be no 'us' without a 'them"' (Billig 1995, 78). Thatcherism and Cameronism's One Nation of hard-working Brits-rhetoric masks actual class, social and wealth gaps.

A specific version of right-wing populism does not question the interests of capital and how neoliberalism has instituted a low wage economy, but rather deflects attention from class issues by blaming centralised EU bureaucracy and European migrant workers, especially those from the East and the South, for social problems. It does not argue for Europewide minimum wages at a standardised high level and for a political and social union, but rather says that not the lack of political regulation of class relations, but the free movement of labour across Europe is the problem. Cameronism wants to solve the contradiction between the national character of politics and the global and regional character of capitalism not by universalising workers' rights, but by universalising capital movement and particularising, isolating, dividing, and individualising labour. Cameronism also ignores that migrant workers and students are often deliberately employed at low wages or as unpaid interns and pressured by companies in order to cut wages and jobs and increase profits. The blame is put on migrants instead of companies seeking to maximise profits by extreme exploitation.

In the EU28 countries, the net migration per 1000 inhabitants has increased from 1.4 in 1990 to an average of 2.3 in the years 2005-2013 (data source: Eurostat). In 2013, the EU28 average was 3.2. The UK had a below average value of 3.1. Net migration per 1000 inhabitants was in 2013 higher than in the UK in European countries such as Italy (19.7), Luxembourg (19.0), Switzerland (10.2), Norway (7.7), Malta (7.6), Sweden (6.9), Austria (6.5), Germany (5.6), and Denmark (3.8). 


\begin{tabular}{|l|l|l|l|}
\hline $\begin{array}{l}\text { Net migration, } \\
\mathbf{2 0 0 2 - 2 0 1 3}\end{array}$ & Country & $\begin{array}{l}\text { Population } \\
\mathbf{2 0 1 3}\end{array}$ & $\begin{array}{l}\text { Share of net migration } \\
\text { in total population, in\% }\end{array}$ \\
\hline 83,246 & Luxembourg & 545,200 & 15.3 \\
\hline 92,455 & Cyprus & 867,100 & 10.7 \\
\hline 671,280 & Switzerland & $8,018,400$ & 8.4 \\
\hline $3,614,139$ & Spain & $45,917,800$ & 7.9 \\
\hline 389,884 & Norway & $5,080,000$ & 7.7 \\
\hline $3,862,333$ & Italy & $61,048,700$ & 6.3 \\
\hline 565,194 & Belgium & $11,105,000$ & 5.1 \\
\hline 547,907 & Sweden & $9,600,500$ & 5.7 \\
\hline 229,982 & Ireland & $4,601,800$ & 5.0 \\
\hline 391,552 & Austria & $8,468,600$ & 4.6 \\
\hline 12,546 & Iceland & 323,800 & 3.9 \\
\hline 14,739 & Malta & 423,400 & 3.5 \\
\hline $2,156,224$ & UK & $64,087,000$ & 3.4 \\
\hline 66,893 & Slovenia & $2,059,500$ & 3.2 \\
\hline 146,608 & Finland & $5,438,600$ & 2.7 \\
\hline 140,741 & Denmark & $5,612,000$ & 2.5 \\
\hline 233,148 & Czech Republic & $10,512,600$ & 2.2 \\
\hline $1,771,558$ & Germany & $8,210,4000$ & 2.2 \\
\hline 206,496 & Hungary & $9,893,700$ & 2.1 \\
\hline 777 & Liechtenstein & 36,500 & 2.1 \\
\hline 324,875 & Netherlands & $16,799,600$ & 1.9 \\
\hline 195,409 & Portugal & $10,481,500$ & 1.9 \\
\hline 74,946 & Slovakia & $5,413,000$ & 1.4 \\
\hline 39,082 & Croatia & $4,252,700$ & 0.9 \\
\hline 404,480 & France & $65,741,000$ & 0.6 \\
\hline$-130,408$ & Greece & $11,092,800$ & -1.2 \\
\hline$-463,127$ & Poland & $38,502,400$ & -1.2 \\
\hline$-25,320$ & Estonia & $1,339,700$ & -1.9 \\
\hline$-381,644$ & Romania & $19,983,500$ & -1.9 \\
\hline$-202,490$ & Latvia & $2,014,300$ & -10.1 \\
\hline$-365,469$ & Lithuania & $2,958,200$ & -12.4 \\
\hline & & & \\
\hline & & & \\
\hline
\end{tabular}

Table 1: Net migration in Europe, data source: Eurostat

Table 1 shows that taken all together, the share of net migration in the UK in the years 20022013 makes up $3.4 \%$ of the total 2013 population. This is an average value that 12 other European countries exceed. UK immigration is in European standards not exceptionally high, but at an average level, which shows that mongering fear about immigrants flooding Britain is overdrawn and ideological.

\section{From Thatcherism to Cameronism}

Cameronism is a specific form of Thatcherism that has the flexibility to discard, intensify and vary the latter's elements and to take on additional moments. Cameron says that Thatcher "was a big influence. [...] I thought she was doing the right thing" (Cameron and Jones 2010, 34). He argues that Thatcherism was about transforming the economy and "that we need a similar scale of transformation in terms of our society" (Cameron and Jones 2010, 309).

In the realm of the economy, Cameronism just like Thatcherism fosters free market radicalism by advancing the discourse of the Conservatives' competence in economic management VS. economic chaos caused by the Labour Party, advances an ideology of hard labour and a blue-collar Conservatism, whose ideological trick is to divert public attention from the actual strengthening of the interests of the rich and corporations, the class conflict and its social inequality and the power of capital and finance by appealing to other (lower economic) 
classes' aspirations to own and purchase private homes and to class mobility, i.e. the desire to master the transition to the middle, upper-middle or upper-class. Cameronism argues that the hurdle for the actual realisation of such desires are immigrants, welfare recipients, the unemployed, the poor, gangs, criminals, terrorists, and the European Union. The ideological character of blue-collar Conservatism is also shown by Cameronism's anti-union politics.

At the level of politics, Cameronism fuses Euroscepticism and authoritarian state politics. Just like Thatcherism it advances a non-interventionist state in economic politics and a strong state in the realms of law and order, security, and surveillance. Cameronism favours low taxes in general and particular for corporations, the rich and the middle class combined with cuts to welfare and the social system. It uses ideologies and the politics of scapegoating for trying to deflect attention from its own class politics. It manages the class contradiction by favouring a pure neoliberalism that is based on the free movement of capital in Europe and the world, restrictions of the mobility of labour and of social policies to the nation state so that capital's interests and powers are strengthened.

A free market-critique and a nationalist critique of Europe are elements of both Thatcherism and Cameronism. Thatcher regarded Europe under Jacques Delors as a potential socialist threat. "Thatcher's growing hatred of the EC owed much more to its collectivist aspects and its commitment to 'improving' social policies than it did to its challenge to British sovereignty. Playing the patriotic card, however, won greater political dividends with the right wing of her party" (Evans 2013, 89). Thatcherism was "anti-European, because it was primarily concerned with the national legitimation of a global neo-liberal economic strategy" (Gifford 2014, 11).

Thatcherism and Cameronism have resulted in a culture of extreme competitive possessive individualism that lacks social and community spirit. The results have been high inequality, especially affecting poverty and the young generation's opportunities, unemployment and income levels. By reducing taxes for the middle and upper classes so that collective public service provision funded by taxes becomes ever more difficult and private services are put on the agenda, society under Cameronism tends to be more unequal and individualised. Inequality is also expressed as unequal access to basic services depending on income levels. Cameronism advances British and English nationalism, traditionalism, the moral explanation of the social, and the values of authority and discipline. It neglects the political economy of capitalism, patriarchy and racism in explaining social problems and reduces them to moral issues.

Ideologies are not abstract entities, but are created and reproduced by ideological workers such as intellectuals, think tanks, or consultants. The Tories not just foster an ideology of labour, but there is also the labour that creates their ideology. On the one hand we can say that the Tories take up free market and neoliberal ideologies that liberal economists created in the $18^{\text {th }}$ century and to which Chicago School economists such as Friedrich August Hayek and Milton Friedman gave a new form in the $20^{\text {th }}$ century. But there are also concrete people who conduct labour in order to develop Conservative ideologies and apply them to concrete political questions. Pautz (2013) argues that important think tanks working for the Tories include the Institute of Economic Affairs, the Adam Smith Institute, the Centre for Policy Studies, Politeia, Civitas, Policy Exchange, Reform, the Centre for Social Justice, and ResPublica.

Ideological workers supporting Cameronism can also be found in the media, for example in the right-wing press that includes newspapers such as The Sun, The Times, the Daily Mail, the Daily Telegraph, or the Daily Express. For fostering Cameronism, such outlets have for example featured articles with titles such as "The man who hated Britain: Red Ed's pledge to bring back socialism is a homage to his Marxist father" ${ }^{23}$ or cover pages with an unfavourable image showing Ed Miliband eating a bacon sandwich combined with slogans such as "Save our bacon: Don't swallow his porkies and keep him OUT. TODAY The Sun exposes

\footnotetext{
${ }^{23}$ The man who hated Britain: Red Ed's pledge to bring back socialism is a homage to his Marxist father. Daily Mail Online, September 27, 2013.

http://www.dailymail.co.uk/news/article-2435751/Red-Eds-pledge-bring-socialism-homage-Marxist-father-RalphMiliband-says-GEOFFREY-LEVY.html
} 
Ed Miliband's lies and asks YOU to vote Tory to insure that his wreckless socialism does not put a halt to Britain's recovery"24. Popular media have also helped to diffuse Tory values, especially TV shows such as Channel 4's Benefits Street, Benefits Britain 1949, and Immigration Street, the BBC's We All Pay Your Benefits, The Apprentice, Britain on the Fiddle; Famous, Rich and Hungry; Britain's Hardest Grafter, or Channel 5's Gypsies on Benefits and Proud.

All of these elements show that Cameronism is (just like Blairism) the continuation of Thatcherism. But are there also significant differences between Thatcherism and Cameronism? In the realm of immigration policies, the scapegoating of migrant workers, Europscepticism and surveillance politics, Cameronism shows qualitative differences to Thatcherism and turns authoritarian populism into concrete authoritarian politics.

Thatcher combined anti-immigrant rhetoric with a "light touch policy agenda on immigration" so that "immigration policy remained largely untouched throughout the Thatcher premiership" (Olad 2013). In 1978, Thatcher said in an interview that "people are really rather afraid that this country might be rather swamped by people with a different culture" and that "if you want good race relations, you have got to allay peoples' fears on numbers" 25 . There are parallels between Cameron and Thatcher's immigration rhetoric. A difference is, however, that Cameronism more than Thatcherism has implemented anti-immigrant policies, such as the surveillance of non-EU students at universities, requirements for banks and landlords to check the immigration status of customers and tenants, the deportation of criminals prior to the hearing of appeals, the reduction of unemployment benefits for non-British EU citizens from six to three months, or health care surcharges for non-EU citizens. Cameron also announced passing a communications bill that intensifies online surveillance by requiring service providers to retain communications data of phone calls, e-mails, web browsing, social media, voice over IP and online gaming. In their 2015 Election Manifestos, the Tories wrote that the Human Rights Act that is based on the European Convention of Human Rights should be scraped in order to limit migrants' human rights, to limit the right to family life for non-EU spouses of British and EU citizens living in the UK, and to limit the free movement of workers coming to the UK from EU countries. "We must work to control immigration and put Britain first" (D10, 29).

Since the 1990s, the world situation has seen an intensified globalisation of the economy, culture and society, the supersession of the Eastern block by a brutal neoliberalism combined with corruption and wars, the growth of the European Union from 9 countries with a population of 250 million to a large supranational regional block with 28 countries and more than 500 million inhabitants in 2015 (data source: Eurostat), continuous wars in the Middle East and Africa. Given these changes, it has become a very common phenomenon for many people that they throughout their life, they live in different countries. Such mobility has to do with both forced and voluntary migration. These developments have come along with racist anti-immigrant ideologies that stress "bogus" asylum seekers, Islamic terrorists, Polish plumbers and other workers from Romania, Bulgaria or Albania that dump wages, benefit tourism, criminal gangs from Eastern Europe, immigrants exerting pressures on the housing market and the NHS, knife crime committed by black youth, health tourism, etc. (Smith 2010). Such rhetoric has created a feedback loop between right-wing tabloid media and right-wing politics that calls for tough measures on immigration (Smith 2010). Cameronism is among other things a manifestation of this development.

The relationship of Thatcherism and Cameronism can be observed by comparing the Queen's Speeches under Thatcher (1979-1990) with the one in 2015 under a Cameron-led Tory majority. Table 2 shows elements that were foregrounded in each of these speeches. The Queen's Speech is held annually at the State Opening of Parliament and introduces the government's planned programme for the coming year.

\footnotetext{
${ }^{24}$ The Sun, May 6, 2015.

${ }^{25}$ http://www.margaretthatcher.org/document/103485; https://www.youtube.com/watch?v=sHhKI5ijnxQ
} 


\begin{tabular}{|l|l|l|l|l|l|l|l|l|l|l|l|l|l|}
\hline Year: & 79 & 80 & 81 & 82 & 83 & 84 & 85 & 86 & 87 & 88 & 89 & 90 & 2015 \\
\hline ECONOMY: & & & & & & & & & & & & & \\
\hline $\begin{array}{l}\text { Commodification, } \\
\text { privatisation }\end{array}$ & + & + & + & + & + & + & + & + & + & + & + & + & + \\
\hline Financialisation & & + & + & + & + & + & + & + & + & + & & & \\
\hline $\begin{array}{l}\text { Attack on working } \\
\text { class interests }\end{array}$ & + & & + & + & + & + & + & & + & & + & & + \\
\hline STATE: & & & & & & & & & & & & & \\
\hline Self-regulation & + & + & & & + & + & + & & & + & & & + \\
\hline Law and order state & + & & & + & + & + & + & + & + & + & + & + & + \\
\hline Militarisation & + & + & + & + & + & + & + & + & + & + & + & + & + \\
\hline $\begin{array}{l}\text { Social cuts, public } \\
\text { spending cuts }\end{array}$ & + & + & + & + & + & + & + & + & + & + & + & + & + \\
\hline Neoliberal taxation & + & & & & + & & + & + & + & + & & & + \\
\hline CULTURE: & & & & & & & & & & & & & \\
\hline Individualism & & + & + & + & & + & & + & + & + & + & & \\
\hline $\begin{array}{l}\text { Traditionalism, na- } \\
\text { tionalism, patriotism }\end{array}$ & & & & & & & & & + & + & & + & + \\
\hline
\end{tabular}

Table 2: Elements of Thatcherism in the Queen's Speeches under Thatcher and Cameron

There are many parallels between the 2015 Queen's Speech and the ones under Thatcher. These parallels concern especially privatisation, attacks on working class organisations, business self-regulation, law and order politics, taxation, and national identity.

The 2015 Queen's Speech confirmed the analysis of Cameronism set out in this paper. Some of the announced measures aim to garner middle and working class support and are an expression of the strategy of blue collar Conservatism: the freezing of income tax, VAT and national insurance levels, the extension of free child care for 3-4 year olds to 30 hours per week, housing association tenants' right to buy their homes, or the improvement of the access to GPs. Cameronism fosters low taxation levels, which can pose problems for public services. It also advances the further privatisation of housing.

On the economic level, the Queen's Speech announced advancing further privatisation in the housing sector and a trade union law according to which members have to opt in (and not out as thus far) to political levies paid by unions to the Labour Party and there must be a turnout of at least $50 \%$ at strike ballots in the public sector.

On the political level, welfare cuts were announced: a reduction of benefits cap, a requirement for young people to "earn or learn", and a limitation of housing benefits for 18-21 year olds. Concerning security, an extremism bill and an investigatory powers bill that extends the state's surveillance capacities to social media use, web browsing and the bulk collection of communication data ${ }^{26}$ were planned.

The most significant difference to Queen's Speeches under Thatcher concerns national identity. Limits to immigration and the relation to the European Union were under Thatcher only mentioned directly once, namely in 1987: "My Government will play a leading role in the development of the European Community while safeguarding Britain's essential national interests". The same Speech argued that a "Bill will be introduced to reinforce the system of firm but fair immigration control".

The 2015 Queen's Speech's formulation that the government takes a "one nation approach" shows that British political and cultural identity is important for the government. It is afraid of Scottish independence, which is why the Speech devolution of powers to Scotland, Wales and cities. Such devolution is coupled to the introduction of the principle of English votes for English laws. The Speech was Euro-sceptic: It announced a renegotiation of the UK's relationship to the EU and an in/out referendum before the end of 2017. It also mentioned a British Bill of Rights, which could mean Britain's withdrawal from the European Convention on Human Rights (ECHR). Such a move could also pose constitutional and institu-

\footnotetext{
${ }^{26}$ Security services' powers to be extended in wide-ranging surveillance bill. The Guardian Online, May 27, 2015. http://www.theguardian.com/uk-news/2015/may/27/security-services-investigatory-powers-bill
} 
tional problems because the Scotland Act 1998 legislates that the laws the Scottish parliament passes must be compatible with the ECHR and the Good Friday Agreement that governs the political relationship between the UK, Northern Ireland and Ireland legislates that Northern Ireland law must respect the ECHR.

The 2015 Queen's Speech is an indication that Cameronism pits "the British" against immigrants, welfare recipients, trade unions, young people, and the European Union that are constructed as unproductive and a drain on resources.

\section{Conclusion}

Both Thatcherism and Cameronism emerged during the course of world economic crises. Such crises do in no way determine political and ideological life, but are often times of high uncertainty for the future of political life. They tend to condition social and ideological struggles. In countries such as Spain and Greece, the Left organised itself in large social movements and as popular political parties and could partly seize power. In Britain, the Left is historically particularly weak. It could not to a sufficient extent organise itself and reach out to popular sentiments and common sense in the situation of crisis. The Labour Party for a long time did not represent a clear alternative to the Tories, but rather continuously presents itself as, as Nicola Sturgeon argued in a BBC debate, as "Tory light" ${ }^{27}$. The 2015 general elections wiped out the Labour Party in Scotland and resulted in the SNP holding the overwhelming majority of the Scottish MPs.

This development is politically significant because it shows that it is possible to challenge Cameronism by a contemporary form of social democracy. The lack of a profound Left message contributed to the Tories' convincing significant parts of the upper, middle and lower classes that low tax regimes for companies and the middle and upper classes combined with a strong state and politics directed against immigrants and the weak are a way forward.

The profound victory of Jeremy Corbyn in the 2015 Labour Party leadership election has shifted the party more towards the Left. Corbyn is a socialist politician who has a vision for society that is very different from Cameronism. The rise of Corbynism faces the contradiction that the Labour Party base supports Corbyn, whereas the Parliamentary Labour Party is predominately Blairite and deeply opposes him. At the same time, the 2016 EU Referendum resulted in a deep split in the Conservative Parties between those who want to leave the EU and those who want to stay in under the agreement that Cameron negotiated. The manifold contradictions the two parties face make the future until the next UK general election in 2020 quite unpredictable and therefore also open for both opportunities and risks.

Cameron's majority government won the ideological struggle in the immediate aftermath of the world economic crisis in Britain. Cameronism sets out to contain class struggles, strengthening the interests of the rich and companies and to ideologically sell such politics to the people in their name, although it is directed against their very interests.

The question of Britain's regional, national, European and global identity is one of the main political and one of the most controversial issues in Cameron's government that was formed in May 2015. Cameronism combines neoliberalism with national-popular policies, anti-trade unionism, British nationalism, an anti-immigration ideology, Euroscepticism, and law and order politics. It is a continuation and intensification of Thatcherism that is not just a form of Conservative and right-wing politics, but a politics that has strong authoritarian potentials.

Margaret Thatcher was a divisive figure. When she resigned in 1990 , out of 2,000 respondents in a survey, $60 \%$ disliked her and $62 \%$ argued she was out of touch with reality ${ }^{28}$. Especially the poll tax, cuts to the NHS and privatisations, her taxation policies, that she saw

\footnotetext{
${ }^{27}$ https://www.youtube.com/watch?v=4anBsb1Go3c

28 https://www.ipsos-mori.com/Assets/Docs/Infographics/ipsos-mori-margaret-thatcher-infographic.pdf
} 
lowering inflation more important than reducing unemployment ${ }^{29}$, were very unpopular Thatcherite measures ${ }^{30}$.

The election success and sustainability of Cameronism may partly have to do with the failures of progressive forces, including the Labour Party, to present a popular alternative to Cameronism, a decentralised $21^{\text {st }}$ century socialism that combines the role of civil society and the state, and the failure to present Cameronism as Thatcherism 2.0 (or Thatcherism 4.0 if one considers Majorism as Thatcherism 2.0 and Blairism as Thatcherism $3.0^{31}$ ) and $21^{\text {st }}$ century Thatcherism. The struggle against Cameronism is first and foremost an ideological one that needs to break with the image of "Thatcherism and Cameronism light" and construct an alternative popular vision for society. Corbynism is a socialist force that contradicts Cameronism, but is itself internally contradicted by the Labour Party's own version of Thatcherism. Contemporary British politics is highly antagonistic and shaped by ideological struggles between neoliberalism and democratic socialism.

\section{References}

Ali, Tariq. 2015a. The Extreme Centre. A Warning. London: Verso.

Ali, Tariq. 2015b. The New World Disorder. London Review of Books 37 (7): 19-22.

Antonio, Robert J. 1981. Immanent Critique as the Core of Critical Theory: Its Origins and Developments in Hegel, Marx and Contemporary Thought. The British Journal of Sociology 32 (3): 330345.

Billig, Michael. 1995. Banal Nationalism. Los Angeles, CA: Sage.

Cameron, David and Dylan Jones. 2010. Cameron on Cameron. Conversations with Dylan Jones. London: Fourth Estate.

Evans, Eric J. 2013. Thatcher and Thatcherism. London: Routledge. Third edition.

Fairclough, Norman, Jane Mulderrig and Ruth Wodak. 2011. Critical Discourse Analysis. In Discourse Studies. A Multidisciplinary Introduction, ed. Teun A. van Dijk, 357-378. London: Sage.

Finlayson, Alan. 2007. Making Sense of David Cameron. Public Policy Research 4 (1): 3-10.

Fuchs, Christian. 2015. Culture and Economy in the Age of Social Media. New York: Routledge.

Fuchs, Christian. 2014. Social Media: A Critical Introduction. London: Sage.

Fuchs, Christian. 2008. Internet and Society: Social Theory in the Information Age. New York: Routledge.

Gifford, Chris. 2014. The Making of Eurosceptic Britain. Farnham: Ashgate. Second edition.

Hall, Peter. 1986. Governing the Economy. The Politics of State Intervention in Britain and France. Cambridge: Polity.

Hall, Stuart. 1997. The Local and the Global: Globalization and Ethnicity. In Culture, Globalization and the World-System: Contemporary Conditions for the Representation of Identity, ed. Anthony D. King, 19-40. Minneapolis, MN: University of Minnesota Press.

Hall, Stuart. 1988a. The Hard Road to Renewal. Thatcherism and the Crisis of the Left. London: Lawrence \& Wishart.

Hall, Stuart. 1988b. The Toad in the Garden: Thatcherism among the Theorists. In Marxism and the Interpretation of Culture, ed. Cary Nelson and Lawrence Grossberg, 35-73. Urbana, IL: University of Illinois Press.

Hall, Stuart and Martin Jacques, eds. 1983. The Politics of Thatcherism. London: Lawrence \& Wishart.

Hall, Stuart and Martin Jacques, eds. 1989. New Times: Changing Faces of Politics in the 1990's. London: Lawrence \& Wishart.

Hay, Colin and Stephen Farrall. 2014. Interrogating and Conceptualizing the Legacy of Thatcherism. In The Legacy of Thatcherism, ed. Colin Hay and Stephen Farrall, 3-30. Oxford: Oxford University Press.

Institute for Fiscal Studies. 2015. Public Finances under the Coalition. London: IFS.

Institute for Fiscal Studies. 2014. Living Standards, Poverty and Inequality in the UK: 2014. London: IFS.

\footnotetext{
${ }^{29}$ Opinion on Margaret Thatcher remains divided after her death, poll finds. The Guardian Online, April 9, 2013. http://www.theguardian.com/politics/2013/apr/09/opinion-sharply-divide-margaret-thatcher

${ }_{30}$ https://www.ipsos-mori.com/researchpublications/researcharchive/3158/Margaret-Thatcher-19252013.aspx

31 Richard Seymour $(2010,16-17)$ argues that Cameronism just like Blairism wants to "restore the social power and profitability of capital after the turbulent Seventies by breaking the power of organised labour".
} 
Jessop, Bob, Kevin Bonnett, Simon Bromley and Tom Ling. 1988. Thatcherism. A Tale of Two Nations. Cambridge: Polity.

Jewkes, Yvonne. 2011. Media \& Crime. London: SAGE. Second edition.

Kerr, Peter, Christopher Byrne and Emma Foster. 2011. Theorising Cameronism. Political Studies Review 9 (2): 193-207.

Kumar, Krishan. 2003. The Making of English National Identity. Cambridge: Cambridge University Press.

Littler, Jo. 2013. Meritocracy as Plutocracy: The Marketising of "Equality" within Neoliberalism. New Formations 80/81: 52-72.

Marsh, David and R.A. W. Rhodes, eds. 1992. Implementing Thatcherite Policies: Audit of an Era. Buckingham: Open University Press.

McGuigan, Jim. 1992. Cultural Populism. London: Routledge.

Olad, Awale. 2013. What Was Thatcher's Legacy on Immigration? http://www.migrantsrights.org.uk/blog/2013/04/what-was-thatcher-s-legacy-immigration

Pautz, Hartwig. 2013. The Think Tanks Behind 'Cameronism'. The British Journal of Politics and International Relations 15 (3): 362-377.

Reyes, Oscar. 2007. A New Political Landscape. Engaging with Cameronism. Renewal 15 (2/3): 8388.

Seymour, Richard. 2010. The Meaning of David Cameron. Winchester: Zero Books.

Smith, Evan. 2010. "Managing" Migration: Discourses on Immigration and "Race Relations" from Thatcherism to New Labour. In Domestic Policy Discourses in the US and the UK in the "New World Order", ed. Lori Maguire, 251-288. Newcastle upon Tyne: Cambridge Scholars Publishing.

van Dijk, Teun. 2011. Discourse and Ideology. In Discourse Studies. A Multidisciplinary Introduction, ed. Teun van Dijk, 379-407. London: Sage.

Williams, Raymond. 1989. Resources of Hope. Culture, Democracy, Socialism. London: Verso.

Williams, Raymond and Jim McGuigan. 2015. A Short Counter-Revolution: Towards 2000 Revisited. London: Sage.

\section{About the Author}

Christian Fuchs

Christian Fuchs is co-editor of tripleC: Communication, Capitalism \& Critique (http://www.triple-c.at). $\mathrm{He}$ is a professor at the University of Westminster, where he is Director of the Communication and Media Research Institute (CAMRI, http://www.westminster.ac.uk/camri) and Director of the Westminster Institute for Advanced Studies (WIAS, http://www.westminster.ac.uk/wias). He is a member of the European Sociological Association's Executive Committee. His books include "Reading Marx in the Information Age: A Media and Communication Studies Perspective on Capital Volume 1" (2016), "Culture and Economy in the Age of Social Media" (2015), "Digital Labour and Karl Marx" (2014), "Social Media: A Critical Introduction" (2014), "OccupyMedia! The Occupy Movement and Social Media in Crisis Capitalism" (2014), "Foundations of Critical Media and Information Studies" (2011), "Internet and Society: Social Theory in the Information Age" (2008).

http://fuchs.uti.at

@fuchschristian 